\title{
CONCEPTUALIZING THE QATARI-AFRICAN FOREIGN POLICY AND ECONOIMIC RELATIONS: THE CASE OF SOFT POWER
}

\author{
Ben O'Bright*
}

\begin{abstract}
Using a case study approach, this article examines the shifting dimensions of Qatar's international relations strategies with select, geo-politically important African states, including primarily the latter's private sector and civil society, and focusing on the current or potential use of soft power in particular. To start, this article presents a comprehensive overview of soft power, including its international relations theory-based historical origins; definitional boundaries; associated tools and mechanisms; and the concept's pragmatic problems and limitations. Second, the article offers several best practice case studies, including the United Kingdom and China, from which core lessons on soft power development and application can be gleaned. This will advance from a list of seven key lessons that any prospective soft power state should consider. Following this, the article engages in an examination of available evidence outlining Qatar's attempted soft power action on the African continent and, particularly in Sudan, Somalia, Mali and Tunisia, arguing that it relies extensively on "carrotdiplomacy" or the influencing of others backed by material and financial resource inducements. Finally, five problems and roadblocks affecting Qatar's approach to international relations will be presented, followed by alternative (soft) power-based strategies, which could be explored by its government and leadership.
\end{abstract}

Keywords: Soft Power; Qatar; Africa; Sudan; Somalia; International Relations; United Kingdom.

DOI: https://dx.doi.org/10.4314/jsdlp.v8i1.4

\section{INTRODUCTION}

The 1940s and 1950s mark a beginning of the concept of state-driven power, a hallmark of the political science and international relations

* PhD Candidate, Dalhousie University and Researcher, Centre on Governance, University of Ottawa. 
debate. Indeed, an understanding of power differentiates much of the theoretical ground within this field. In the view of Hans Morgenthau, the concept of power must continue to be the theoretical core of international politics as, in his view, all politics is a struggle for power. ${ }^{1}$ This perspective is derived from his understanding that the desire to dominate is a constitutive element of all human associations, thus indicating that international pressure and geopolitics is simply a struggle between independent units seeking to maximize their own power so as to control others. ${ }^{2}$

In a global society, however, where much has changed since the writings of Morgenthau, can we truly continue to proceed down the conceptually limited intellectual path? As Barnett and Duvall argue, our perspective of international relations and elements within it is primarily guided by a realist's conception of power - the ability of states to use material resources to get others to do what they otherwise might not. ${ }^{3}$

Using a case study approach, this article will examine the shifting dimensions of Qatar's international relations strategies with select, geopolitically important African states, including primarily the latter's private sector and civil society; while focusing on the current or potential use of soft power in particular. Put another way, this article will ask whether soft power, as a multidimensional concept, with a variety of theoretical and normative understandings, can help (and, specifically, how) in achieving or furthering Qatari business interests and foreign policy objectives on the African continent.

Tostart, this article presents a comprehensive overview of soft power, including its international relations theory-based historical origins, definitional boundaries, associated tools and mechanisms, and the concept's pragmatic problems and limitations. Secondly, the article presents several best practice case studies, including the United Kingdom, which has been consistently ranked as a leading soft power, as has been China. Thirdly, to build further from those cases, a list of seven key lessons that any prospective soft power state should consider is provided. Delving deeper into the Qatari example, this country will

1 K. J. Holsti, "The Concept of Power in the Study of International Relations" (1964), 7(4) Background, 179.

2 ibid.

3 Michael Barnett \& Raymond Duvall, "Power in International Politics" (2005) 59(1) International Organization, 40. 
be shown to have back stopped its emerging international power as a small Gulf State with substantial hard economic resources. Equally, Qatar's extensive soft power toolset will be analysed, denoting the country's efforts to build for itself an attractive brand abroad as a means of persuading targeted states to come closer to it.

Sequel to this, the article engages in an examination of available evidence outlining Qatar's attempted soft power action on the African continent, particularly in Sudan, Somalia, Mali and Tunisia, arguing that it relies extensively on "carrotdiplomacy" or influencing others backed by material and financial resource inducements. Finally, five problems and roadblocks affecting Qatar's approach to international relations will be presented, followed by alternative (soft) power-based strategies, which could be explored by its government and leadership.

\section{SOFT POWER}

\subsection{Historically Realist}

Perhaps the most appropriate place to start a definition of soft power is to identify what it actually is not. Traditional notions of power, primarily derived from the realist school of international relations scholarships, focused on an entity's ability to dominate and control. Waltz, in his Theory of International Politics, describes the international system as one source in a balance of power theory. This theory assumes that states, at a minimum level, seek their own preservation and, at a maximum, drive for ultimate domination. ${ }^{4}$ Waltz argues that this could be achieved internally by increasing economic power or military strength and, externally, by increasing the forces associated with one's own alliances while weakening that of an opposing state. ${ }^{5}$ Even with the advent of nuclear weapons and a strategy of deterrence between the former Soviet Union and the United States, Waltz maintained that, in the international system, military force as power had hardly lost its meaning or usefulness. ${ }^{6}$ For Hart, there are several components of such a measurement of state power, namely, control over resources, including

4 Kenneth Waltz, Theory of International Politic (Long Grove: Waveland Press Inc., 1979), 117.

5 ibid.

6 Kenneth Waltz, "The Emerging Structure of the International System" (1993) 18(2) International Security, 53. 
military expenditure; the size of armed forces; the gross national product and population; control over actors or, in the words of Dahl, the ability of $A$ to get $B$ to do something that he would otherwise not do; and control over events and their outcomes. ${ }^{7}$ Interestingly, Hart leaves open the possibility of control in the second case, as it could either stem from coercion, namely military; or persuasion aptly termed influence. ${ }^{8}$ This distinction will become critically important in the coming pages, for soft power largely rests on the latter.

In a situation of international anarchy, which realists classically identified as pervasive among states, force is seen as an integral part of foreign policy because military power can be used both forcefully and peacefully. ${ }^{9}$ The latter comprises threats to harm, cripple or destroy but not to actually do so while the former operates in the physical sense, whereby state A harms or destroys the possessions of state B. ${ }^{10}$ In both cases, however, power is related directly to a state's ability to cause militarily damage to another state. Hart continues by arguing that force, such as military power, is integral to statecraft because international politics is inherently anarchical. ${ }^{11}$ To achieve their own designated policy objectives and interests, this perspective argues that coercion, persuasion or influence, as Hart notes above, is fundamentally ineffective without hard power backing or the threat of such power.

\subsection{Determining the Boundaries of Soft Power}

With this in mind, what then might constitute notions of soft power? It is generally agreed that Joseph Nye coined the term in the early 1990s, first in his book, Bound to Lead: The Changing Nature of American Power, and then elaborated upon it in subsequent works. Nye observes that, as we saw above, the traditional test of a great power was its strength in war but, today, that definition of power that emphasizes military force and conquest has been losing its validity due to

7 Jeffrey Hart, "Three Approaches to the Measurement of Power in International Relations" (1976) 30 (2) International Organization, 290-296.

8 ibid 291.

9 Robert J Art, "The Fungibility of Force" in Robert J Art and Kenneth N Waltz (eds), The Use of Force - Military Power and International Politics (Oxford: Rowman and Littlefield Publishers Inc., 2004), 3.

10 ibid.

11 ibid 5. 
unconventional threats and transnational, borderless issues. ${ }^{12}$ Proof of the power of this doctrine comes not from a state's measurable resources, but in its ability to change the behaviour of states in general. ${ }^{13}$

It would appear now that the direct use of hard, material force for economic and positional gainis generally too costly and dangerous for modern hegemonic powers. ${ }^{14}$ Nye argues that this is specifically due to five major trends, namely increased economic interdependence between states powered by revolutions in information; communications and transportation technology; the rise of transnational actors who predominantly exert influence by effecting the ways in which national interests are originally defined by policy-makers; a social awakening that has stirred nationalism in developing states, which limits the capacity for external actors to apply military force; the spread of modern technology, which enhanced the capabilities of those same developing states; and the increasing transnational nature of political, economic, security and cultural issues in world politics, which require multilateral responses. ${ }^{15}$

The changes noted suggest a variation in the way of exercising power beyond traditional means, including the hegemonic control of natural resources and territorial conquest, which Nye terms as soft power - a country may obtain the outcomes it wants in world politics because other states, who admire its values, emulate its examples and aspire to its level of prosperity and openness - want to follow it. ${ }^{16}$ Soft power co-opts rather than coerces others - it has the ability to shape their preferences. ${ }^{17}$ It is not merely the same thing as influence, however, as influence can also rest on the hard power of threats, attacks and payments. ${ }^{18}$ Rather, Nye firmly believes that soft power is, in behavioural terms, the power of attraction and example, facilitated by material resources. ${ }^{19}$ In later texts, Nye clarifies this division between influence

12 Joseph S Nye, Jr, "Soft Power" (1990), 80 Foreign Policy 154.

13 ibid 155.

14 Ibid 160.

15 Ibid 160-163.

16 Joseph S. Nye, Jr, Soft Power - The Means to Success in World Politics (New York: Public Affairs, 2004), 5.

17 ibid.

18 ibid 6.

19 ibid. 
and attraction, commenting that, while soft power is not just the former, it is still a source of influence. ${ }^{20}$

Since Nye, others have sought to adjust this definition of soft power in the face of changes to both states and the world system at large. In the context of China, its government tends to enunciate a broader idea of soft power - one which means anything outside of the military and security realms, including not only pop culture and public diplomacy, but also more "coercive economic and diplomatic levers" like aid, investment and participation in multilateral organizations. ${ }^{21}$ Kurlantzick equally adds to the definition by differentiating between soft power, which is directed "high" at a country's eliteor "low" at its general public. ${ }^{22}$ This reflects an important point noted by Codevilla whereby soft power does not necessarily have universal applicability in a targeted state. Rather, different parts of populations are attracted or repelled by varied ideas, images and prospects. ${ }^{23}$

\subsection{Tools and Mechanisms of Soft Power}

Nye believed that it is via the instrument of public diplomacy that soft power is diffused abroad. ${ }^{24}$ Public diplomacy is divided by the author into two categories: namely broadcasting or the diffusion of particular information so as to enhance a country's reputation and image; and action with states opting to employ physical resources abroad in order to develop their own state "brand". ${ }^{25}$ It tries to attract, influence and persuade by drawing attention to these potential soft power resources, via broadcasting, subsidizing cultural exports and arranging exchanges. ${ }^{26}$ Thus, public diplomacy is inherently related to the mantra of "information as power" because, as information and communication technologies (ICT) continue to expand dramatically with advances in

20 Joseph S Nye Jr, "Public Diplomacy and Soft Power" (2008) 616 The ANNALS of the American Academy of Political and Social Science 95.

21 Joshua Kurlantzick, Charm Offensive: How China's Soft Power is Transforming the World(New York: Caravan Books, 2007) 6.

22 ibid.

23 Angela M Codevilla, "Political Warfare: A Set of Means for Achieving Political Ends" in J Michael Waller (ed), Strategic Influence: Public Diplomacy, Counterpropaganda and Political Warfare(Washington: Institute of World Politics Press, 2007) 214.

24 Nye (n 17)95.

25 ibid 102, 104.

26 ibid. 
both technology and reach, the ability for a state to unilaterally control its own reputation and credibility becomes diminished. ${ }^{27}$ States, in short, have to find the means of swimming against what could be a current of bad publicity derived from multiple mediums, so as to gain related soft power.

The tools and mechanisms of soft power, which would allow a state to combat the above bad publicity, rest on three resources that a country may or may not possess. These are its culture, political values and foreign policies. ${ }^{28}$ Starting with the first resource, when a country's culture includes universal values and its policies promote those values, traditions and interests that other states may share, the probability of obtaining the desired outcomes increases. ${ }^{29}$ As a consequence, narrow cultural values are unlikely to produce soft power. ${ }^{30}$ The tools of cultural transmission, as a means of generating that soft power, are said to include commerce, personal contacts, visits and exchanges (including overseas education) between state elite, and government policies at home and abroad. ${ }^{31}$ As an example of the latter, during the 1950s, American soft power was curtailed in Africa due to racial segregation policies at home. ${ }^{32}$ This represents what could be considered a hard and fast rule of soft power: Domestic and foreign policies that appear to be hypocritical, arrogant, indifferent to the opinion of others or based on a narrow approach to national interests can undermine soft power. ${ }^{33}$

It is equally important to recall that, unlike hard power, whereby the state traditionally has a monopoly on the use of force, soft power is diffuse - meaning that, while the government may be espousing particular policies or perspectives, public and private sources can simultaneously be working at cross purposes. ${ }^{34}$ States can develop soft power simply by paying attention to others, listening and participating in international forums or engaging with foreign states in dialogue. ${ }^{35}$

27 ibid 100.

28 Nye (n 13) 11.

29 ibid.

30 ibid.

31 ibid13.

32 ibid.

33 ibid.

34 ibid 15.

35 Alexander L. Vuving, "How Soft Power Works" (Conference paper presented at the Annual Meeting of the American Political Science Association in Toronto, 2009) 14. 
In a more direct manner, states can gain soft power via the provision of humanitarian assistance, economic assistance via official development assistance (ODA) or foreign direct investment, as well as via diplomatic endeavours. ${ }^{36}$

Additional research pointed to alternative tools or mechanisms, which could be used to generate soft power. Matlary echoes Nye by citing diplomacy but adds the need for the building of interdependence rather than confrontation as a means of doing so. ${ }^{37}$ Gill and Huang argue that the establishment of cultural education organizations, like the Confucius Institute from China, could assist in projecting a particular image of a state abroad, while the facilitation of tourism - both inbound and outbound - can do the same. ${ }^{38}$ For Turkey, soft power was derived from its increasing eagerness to play the role of third party mediator and manager in the resolution of regional conflict. ${ }^{39}$ Each of these examples provides information crucial to our discussion of the potential for Qatar to become a soft power leader - in the Gulf Region itself but also in areas targeted by its foreign policy and, more especially, the African continent.

\subsection{Best Practices - The United Kingdom}

In 2012, the United Kingdom (UK) was ranked first on the Institute for Government-Monocle's Soft Power Index, a composite measurement framework based on five pillars, namely government or the attractiveness of a state's model of governance; culture, when a country promotes universal values that others identify with and find attractive; diplomacy or the global footprint of a state; the impact of education and related activities; and business/innovation as a measurement of the relative attractiveness of a country's economic model, including its terms of openness, capacity for innovation and quality of its regulation. ${ }^{40}$

36 ibid 14-15.

37 Haaland Matlary Janne, "When Soft Power Turns Hard: Is an EU Strategic Culture Possible?" (2006) 37(1), Security Dialogue 107.

38 Gill Bates \& Yanzhoug Huang, "Sources and Limits of Chinese 'Soft Power"' (2007) 48(2) Survival, 18-20.

39 Meliha Benli Altunisik, "The Possibilities and Limits of Turkey's Soft Power in the Middle East" (2008) 10(2) Inside Turkey, 50.

40 Jonathan McClory,The New Persuaders III - A 2012 Global Ranking of Soft Power (London: Institute for Government, 2012), 7-8. 
The UK had slipped only one position, by $2013 .{ }^{41}$ Therefore, as a relatively stable soft power, as reviewed by one of the few metrics regarding this, what best practices can we glean from the UK, which can then be analysed with reference to our proceeding Qatari case study?

The United Kingdom's Select Committee on Soft Power conducted a comprehensive survey in 2014 on the country's soft power best practices, both in terms of the resources outlined above and the mechanisms for diffusing them. The Committee's principal conclusion was the recognition that innovative diplomacy is key to soft power. The UK has a substantial international presence, with embassies transitioning into "super-facilitators" of British business and civil society with the outside world. ${ }^{42}$ Secondly, they recognized that their armed forces, as mechanisms of hard power, were also ambassadors for soft power, acting as the immediate face of British foreign policy and thus requiring them to have an in-depth understanding of the political and cultural environment in which they operate. ${ }^{43}$ Thirdly, the government traditionally invested substantial material resources into international humanitarian efforts, primarily via their well-recognized Department for International Development. ${ }^{44}$ Linking the latter closely to British values, many of which coincide with what Nye would describe as universal values, the organization becomes a mechanism of attraction and persuasion - not propaganda.

Fourthly, the UK worked to promote itself as a veritable hub for extra-governmental bodies and organizations, as well as an array of international and regional institutions and organizations, resulting in many of them establishing their headquarters in London and other British cities. ${ }^{45}$ These civil society groups add to the country's reputation via their international focus, while simultaneously acting as direct linkages between the UK's normative values and societies abroad. ${ }^{46}$ It

41. Editorial, "Germany Tops World 'Soft Power' Rankings"' The Local (21 November 2013) < http://www.thelocal.de/20131121/germany-number-one-for-softpower $>$ accessed 10 September 2014.

42 United Kingdom House of Lords, "Persuasion and Power in the Modern World First Report" (Select Committee on Soft Power and the UK's Influence, 2014) Chapter 4 paragraphs 98-99.

43 ibid paragraph 111.

44 ibid paragraph 120.

45 ibid paragraph 133.

46 ibid. 
is argued that, becoming a hub for a multitude of international organizational, civil society and cultural networks, allows a country to shape the preferences, debates, procedures, rules and, ultimately, outcomes of decisions they do not necessarily control outright. ${ }^{47}$

The Select Committee observes that the British Monarchy is itself a vessel of soft power influence, with Queen Elizabeth II having made over 260 official visits to 116 different countries during her reign. ${ }^{48}$ The Monarchy acts as a symbol of long-term continuity in government, as a hallmark of collaboration between Republicans and royalty, as well as a champion of British values. ${ }^{49} \mathrm{At}$ home, tourism by foreign visitors amounts to a significant soft power tool. By promoting the UK as an overseas travel destination, including hosting large-scale events like the 2012 Olympic Games, visitors become vessels via which the desired image of the state is transmitted back home. ${ }^{50}$ A seventh best practice adds to this: Regarding education, the UK invested considerable energy into two-way scholarship programmes, international research collaboration opportunities and English language education abroad. ${ }^{51}$

Qatar has an opportunity to learn from these best practices of soft power and has already done so in several areas that will be detailed below. No one particular area of influence is sufficient to achieve meaningful soft power influence; therefore, all must be sustained and cultivated. In this regard, the same Select Committee report determined that after 2012, the UK had forgotten and neglected several of its soft power institutions; funding to the BBC World Service was cut; and rather narrow debates were held on the future of immigration and immigrant population within the UK, thereby damaging the country's image, reputation and persuasive capacity abroad. ${ }^{52}$

47 ibid paragraph 142.

48 ibid paragraph 134.

49 ibid.

50 ibid paragraphs $196-197$

51 ibid paragraphs 207, 212, 218.

52 Indra Adnan, "Soft Power: Britain is Losing its Grip on this Key Asset" The Guardian (31 March 2014) <http://www.theguardian.com/commentisfree/ 2014/mar/31/soft-power-britain-losing-grip-lords-policy > accessed 6 August 2014. 


\section{LIMITS AND PROBLEMS}

Exploring the difficulties and limitations of soft power influence encountered by other states helps generate several key lessons, which Qatar should follow or, at the very least, be wary of in its pursuit of greater soft power influence internationally. Beginning with Nye, the author argues that it is necessary to be sensitive in this regard when soft power might actually function, in that its effectiveness is never guaranteed as uniform across all states at all times. He notes that popular culture is more likely to produce soft power in situations where cultures between two states are similar rather than dissimilar. ${ }^{53}$ Equally, attraction might have a diffuse effect, creating a general influence that may or may not ultimately result in a situation of soft power, rather than the production of an easily observable specific action. ${ }^{54}$ This statement reaffirms Nye's caution that soft power, like hard power, has no guarantee of any results. While soft power can sometimes have a direct impact on specific goals, it is more likely to have an influence on the general goals (or "milieu goals") that a country seeks, such as brand recognition or increasing international prestige and position. ${ }^{55}$

In a study published by the United Kingdom's House of Lords Select Committee on Soft Power and the UK's Influence, testimonial witnesses pointed to difficulties associated with what is termed soft power propaganda. When a government body, actor or institution unilaterally commandeers the control of a cultural mechanism, such as a film production, this action could limit the mechanism's interpretative range and thereby trivializes it, tarnishing the reputation of that mechanism and its operators and removing its ability to strengthen a state's soft power. ${ }^{56}$ Equally, the Select Committee mirrors concerns of Nye and others that soft power is difficult to measure and is largely intangible. ${ }^{57}$ As such, it would seem that the quantitative evaluation of soft power remains an obstacle in terms of pragmatic application by policy-makers.

The Select Committee points to an equally important facet of soft power, namely that it is inherently bound to communication. While the United Kingdom, as this study highlights, may intend to

53 Nye (n 13) 15.

54 ibid 16.

55 ibid.

56 United Kingdom House of Lords (n 43) Chapter 3, paragraph 47.

57 Ibid, paragraph 48. 
communicate a particular message to an audience, the mantra that attraction is in the eye of the beholder will likely remain true, in that the state will often be powerless to control what exactly is attractive about it to others. ${ }^{58}$ Communication is also a bidirectional process. A principal failure of soft power strategies is when the originating country is neither interested in, nor sufficiently flexible to adapt to, the responses it receives for its actions and messages abroad. ${ }^{59}$ Attraction is also affected by what Emile Simpson describes as a say-do gap, whereby the message received by an audience regarding a state does not match the reality that those citizens face. ${ }^{60}$

As an additional example of the limits of soft power, China is being faced with three major hindrances to its effective use. Firstly, it is confronted by an imbalance in soft power resources. While economic growth served as an engine for China's emergence onto the world stage over the past several decades, it was not paralleled by the availability of the "attractive ingredients", which are essential to a soft power recipe, including failure to market itself; a lack of research and innovation in business; limited human development and political freedom; and rampant party corruption - all of which tarnish its image abroad. ${ }^{61}$ Secondly, China faces a legitimacy problem, in that its strategic relationships with dictatorships in the developing world, coupled with a lack of meaningful political reform at home, limits its soft power influence and attractiveness. ${ }^{62}$

According to Nye, states are more likely to endanger greater soft power resources in the information age when they are seen to project ideals, which challenge global norms, including liberalism, pluralism and autonomy. ${ }^{63}$ Evidently, this statement invokes questions of cultural relativity of those so-called global norms and, indeed, it is possible that Beijing may have realized a greater soft power towards those countries that are less westernized and less democratic - according to subjective Western standards. Lacking the ability to influence and persuade the West does not necessary amount to a conjunctive lack in soft power. Instead, it could point to a different target audience. Looking

58 Ibid, paragraph 52.

59 Ibid, paragraph 54.

60 Ibid, paragraph 53.

61 Bates \& Huang (n 39) 27-28.

62 Ibid 28.

63 ibid. 
at Qatar's foreign policy objectives below reveals how we can remove this theoretical weakness by identifying whom we wish to influence.

Finally, China is argued to have significant policy incoherence, which prevents it from advancing a benign and attractive image to others. ${ }^{64}$ Bates and Huang argue that problems with internal economic and policymaking consistency may partially account for the reason why China has not yet been able to reap significant gains in liberal democracies even at a time of softening US prestige. ${ }^{65}$ Qatar would do well to take note of the difficulties and limitations of soft power as outlined above. Indeed, these cases, with their examples of failure and limitation, help support this article's generation of eight key soft power lessons, which should be pursued if Qatar (and others) hopes to adjust and change the interests and actions of others, namely, it is necessary to:

1. Target soft power towards the achievement of general goals, rather than to expect the realization of specific objectives.

2. Be conscious of, and engage in, reconciliation processes regarding historical difficulties, as the latter may contribute to the destabilization of even diffuse cultural and normative influence.

3. Balance soft power resources.

4. Identify one's target audience and their associated global norms, because directing action towards a country with similar normative and ideational characteristics is more likely to be effective than towards those that are dissimilar.

5. Follow a policy of bidirectional communication, in that a country's soft power strategy remains malleable to signals from "influences".

6. Ensure foreign policy coherence, so as to instil a sense of purpose and stability in any observers.

7. Recall that soft power is largely a subjective and relative interpretation of the influence and persuasion that a state has abroad, owing to the difficulties of its quantitative measurement.

8. Recall that soft power is one of many power variants that a state can employ in order to achieve its goals. Soft power itself can equally be considered as an umbrella category for

64 ibid 29.

65 ibid 30. 
other brands of power, including subtle power, smart power and normative power. As such, soft power can never be completely bound by a single definitional explanation.

\subsection{Soft Power and Qatar: A Case of Improving on Success}

So far, we have established some basic information on soft power, including its definition; mechanisms and tools for using it; best practices pioneered by other states; various expected results and associated problems and limitations; as culminated in our list of eight lessons. The next section will analyse our case study of Qatar, including its broad foreign policy goals and stated soft power objectives; its relationship with particular African states; Qatar's own mechanisms for soft power influence, demonstrated via shifting modes of engagement with its partners; the results of its influence and persuasive strategies; as well as associated problems.

\section{FOREIGN POLICY OBJECTIVES}

There are at least five motivations behind Qatar's foreign policy. We demonstrate below that the foreign policy arguably lacks in genuine coherence but largely reflects Kamravian's argument that traditional conceptions of power are no longer adequate to engage with emerging trends, shaping the international system. ${ }^{66} \mathrm{~A}$ state's foreign policy can tell us much about its intended use of soft power tools and the place of those tools within its approach to international relations. First, is the maintenance of the country's own security and stability. ${ }^{67}$ Qatar is located in an area rife with political and military rivalries. Increasing its international profile is directed at preventing the perils of smallstate anonymity and, in particular, a lack of outside awareness of it or relevant impacting issues. ${ }^{68}$ Second, in building its reputation as an effective mediator of conflict, Qatar not only contributes to its first aim by preventing the spillover of regional violence, but it seeks to expand

66 Mehran Kamrava, Qatar: Small State, Big Politics (Ithaca: Cornell University Press 2013), 47.

67 Lina Khatib, “Qatar's Foreign Policy: The Limits of Pragmatism” (2013), 89 (2), International Affairs, 418.

68 ibid. 
its influence as an international player, vis-à-vis Egypt and Saudi Arabia. ${ }^{69}$ Third, Qatar, seeks to appeal to, and leverage the international community, branding itself as a key international ally and a potential host state for global economic activities and businesses. ${ }^{70}$ Fourth, the state's foreign policy has been largely influenced by Qatari approaches to sovereign wealth management, ${ }^{71}$ as well as the maximization of its profits from natural resources, in order to achieve domestic development. ${ }^{72}$ Fifth and, most recently, observers suggested that Qatar had begun to turn away from self-described "arrogant policies" of absolute support for regional Islamist groups and revolutions, signalling a softening in foreign policy goals and a turning to a brand of a neutral mediator. ${ }^{73}$

Qatar's breakthrough into the international system during the 1990s to the mid-2000s is largely credited to its increasingly pervasive role as one of the world's most active mediators of conflict - both in the Middle East and in Africa. ${ }^{74}$ Mediation serves both broad and specific foreign policy objectives. States, such as Qatar, regard mediation as a viable strategy with lower costs than standing by as conflict rages. It also serves as a mechanism for branding Qatar as an international actor and regional powerhouse with a proven public diplomacy track record. ${ }^{75}$ Rather than being a tool of diplomacy, Qatar sees mediation as "diplomacy itself", within a broader framework of strategic action in both international and domestic political systems. ${ }^{76}$ Exemplifying this

69 ibid 419.

70 Ibid 419- 420.

71 Asa Fitch, "Qatar SWF Drops Flashy Deals as Foreign Policy Shift, Report Says" Wall Street Journal (16 June 2014) < http://blogs.wsj.com/middleeast/2014/ 06/16/qatar-swf-drops-flashy-deals-as-foreign-policy-shifts-report-says/> accessed 9 August 2014.

72 Editorial, "Envoy to US Spells Out Qatar's Foreign Policy" Gulf Times (12 July 2014) < http://www.gulf-times.com/qatar/178/details/400164/envoy-to-usspells-out-qatar\%E2\%80\%99s-foreign-policy>.ust> accessed 9 August 2014.

73 Editorial, "Change of Tack" The Economist (15 July 2013) < http:// www.economist.com/blogs/pomegranate/2013/07/qatar-s-foreign-policy > accessed 9 August 2014; Sigurd Neubauer, "Qatar's Changing Foreign Policy" Carnegie Endowment for International Peace(8 April 2014) <http:// carnegieendowment.org/sada/2014/04/08/qatar-s-changing-foreign-policy/ h7gf $>$ accessed 9 August 2014.

74 Mehran Kamrava, "Mediation and Qatari Foreign Policy" Middle East Journal (2011) 65 (4), 539.

75 ibid 541-542.

76 Ibid 542. 
is its interesting, informal open-door type policy of hosting competing and combative factions and groups from abroad, such as Israel and Hamas. ${ }^{77}$ Kamrava argues that, as a relatively new participant in international relations generally, emerging prominently only during the past two decades, Qatar is in the unique position of being free from the accumulated baggage of competitors and neighbours, namely Saudi Arabia and/or Egypt. ${ }^{78}$ Indeed, it may have the capacity to invoke what the author calls subtle power, or the careful balancing of military, cultural and smart power, which allow Qatar to make major, bold and brash foreign policy choices far easier than it would be expected from such a small state. ${ }^{79}$

As recently as 2013, commentators suggested that, while Qatar had been praised for astute public diplomacy and its ability to act as an effective conflict mediator, its foreign policy did not appear to be based on a single coherent political strategy. ${ }^{80}$ The result, according to Khatib, was that, despite some success, Qatar is impacted upon by a discrepancy between image and action. Indeed, with recent shifts in leadership in Qatar (e.g. the replacement of its Foreign Minister), the country appears to be moving away from high-risk, high-visibility foreign policy towards a more conservative approach, ${ }^{81}$ in spite of official signals from leadership regarding "continuity" in the state's approach to international relations. ${ }^{82}$ That said, such a shift may not necessarily represent a haphazard and incoherent approach to foreign policy by Qatar, but rather a return to its former efforts of developing an image and reputation as a mediator, public diplomacy practitioner and stable domestic hub for global affairs, but without any of the earlier associations with foreign policy extremes.

\subsection{Soft Power Objectives and Definitions}

With its emphasis on image branding, particularly as a foreign policy objective in itself, the emphasis that Qatar places on soft power in the

77 Fitch (n 72) 420.

78 Kamrava (n 75) 542.

79 Khatib (n 68) 48-49.

80 Fitch(n 72) 417.

81 Khatib (n 68)

82 Editorial, "No More Own Goals" The Economist (28 September 2014) < http:/ /www.economist.com/news/middle-east-and-africa/21586886-new-emirwants-more-discipline-home-and-less-risk-taking-abroad-no-more-own > accessed 9 August 2014. 
international system is becoming evident. Peterson argues that few countries have taken the lessons and importance of branding more to heart than did Qatar, which approached this strategy from multiple directions. ${ }^{83}$ The author suggests that it has identified itself as distinct from the Gulf Cooperation Council, an organization with which it has a long history of association, and has raised international awareness of itself by hosting large global meetings and conferences and increasing its participation in external alliance institutions and organizations. ${ }^{84}$ Economically, Qatar evolved from its initial branding as an emerging oil and natural gas powerhouse ${ }^{85}$ to a state that recognizes the importance of sustainable resource development, both at home and abroad, as outlined in their National Vision 2030.

It should be recalled that, with approximately 12,000 staff members, Qatar's armed forces are the second smallest in the Middle East, just slightly ahead of Bahrain..$^{86}$ Therefore, under its brand as a Western ally, Qatar has become home to the forward headquarters of the US Central Command, as well as several American military bases, including the largest prepositioning base outside the continental United States. ${ }^{87}$ Such "efforts" provide a three-fold advantage to the state. First, it protects Qatar from any immediate regional threat; second, hosting these bases projects an image of stability abroad;88 and third, it cements the base upon which Qatar can continue to pursue its soft power objectives. Indeed, soft power is necessary for this country because it represents a means of compensating for lack of material and force-based persuasive capabilities.

\subsection{Qatar's Mechanisms for Soft Power Influence}

Beyond the soft power strategy of mediation, the other means by which Qatar both brands itself and projects its image abroad as a means of influencing the interests and actions of others should be highlighted.

83 JE Peterson, "Qatar and the World: Branding for a Micro-State" (2006) 60 (4), Middle East Journal 746.

84 ibid.

85 ibid 747.

86 Christopher M. Blanchard, "Qatar: Background and US Relations" (Congressional Research Service Report 2014), 5.

87 ibid 5-6.

88 Osman Antwi-Boateng, "The Rise of Qatar as a Soft Power and the Challenges" (2013), 2 European Scientific Journal, 40. 
The first, and most widely cited, is the state-owned media outlet, AlJazeera. Its creation in 1996 transformed Qatar from a relatively unknown Gulf State to one with near universal recognition. ${ }^{89}$ As the US successfully did with CNN and the United Kingdom with the BBC, Al-Jazeera has become a wide-reaching means by which Qatar can successfully diffuse its ideals, values and image abroad. ${ }^{90}$ Al-Jazeera now has 65 international bureaus and broadcasts to almost 220 million households in more than 100 countries. ${ }^{91}$ Since its inception, the organization has diversified its coverage to include sport, documen-taries, local news, children's programmes and English language networks. ${ }^{92}$

It was due to its unique coverage of several different events that Al-Jazeera gained its international notoriety, bringing with it a created image of Qatar. In 2000, it capitalized on being the only Arab alternative to coverage of the second Palestinian Intifada and then by being the first to air video messages by Osama bin Laden after the events of September 11th. ${ }^{93}$ Al-Jazeera also effectively used its own branding of media independence to set itself apart as distinct in a region saturated by state-controlled media outlets. ${ }^{94}$ In short, Al-Jazeera acts both as Qatar's cultural bridge ${ }^{95}$ and as a lightning rod to attract the world's gaze to this nation, ${ }^{96}$ thereby establishing an international audience that can be subsequently wooed via alternative soft power strategies and mediums.

The positive impact of investing in sport and the hosting of largescale megaevents on the state's international image and prestige shifted in recent years from being a simply welcome consequence to a significant justification. ${ }^{97}$ Governments use elite types of sport, as a cultural

89 ibid 42.

90 ibid.

91 Editorial, "About Us - Facts and Figures" Al-Jazeera.com (23 Feb 2012) < http:/ /www.aljazeera.com/aboutus/2010/11/20101110131438787482.html> accessed 9 August 2014.

92 Osman (n 89) 43.

93 Fitch (n 72) 426.

94 ibid 427.

95 Timur Akhmetov, "Explaining Qatar's Foreign Policy" Open Democracy (27 February 2012)<https://www.opendemocracy.net/timur-akhmetov/ explaining-qatars-foreign-policy-0 > accessed 4 August 2014.

96 Fitch (n 72) 427.

97 Jonathan Grix \& Barrie Houlihan, "Sports Mega-Events as Part of a Nation's Soft Power Strategy: The Cases of Germany (2006) and the UK (2012)" (2013) The British Journal of Politics and International Relations, 2. 
phenomenon, to achieve foreign policy objectives and, in particular, that of deploying soft power through which states seek to attract others. ${ }^{98}$ Megaevents often serve as a "coming out party" for a country, which will have a guaranteed global audience for their brand, values and image. ${ }^{99}$ Traditionally, Qatar spent considerable effort on the use of sport as a tool of soft power and image promotion abroad. While the country is not a sporting powerhouse, fielding a mere 12 competitors in four events during the 2012 Olympic Games, ${ }^{100}$ it made every effort to both host and have its name appear in many international athletic spectacles. Qatar will host 99 sporting events, including 43 international events between 2014 and 2015. ${ }^{101}$ Five of the latter will be world championships. ${ }^{102}$ Qatar's push to bid for big-ticket tournaments would seem to be less about the value of the sport itself, but the use of sport as a strategic tool to promote itself on the world stage.

Qatar used these global events, including its successful, albeit controversial, bid for the 2022 FIFA World Cup, to once again set itself apart from its regional neighbours. Indeed, since Saudi Arabia, Bahrain and the United Arab Emirates appear to have no intention of hosting large-scale sporting events that Qatar has set its sights on, these abovementioned countries are focusing on niche markets instead. Qatari events and sports strategy brought it closer to its Western counterparts and showcased it as a stable neighbour, host, ally and model for growth. ${ }^{103}$ This latter observation relates to what constitutes a unique tri-directional soft power strategy, which Kamrava termed a balancing act of cultural, financial and military persuasion in the form of subtle power on the part of Qatar. Harkening back to its position as a bridge, Qatar made a conscious and observable effort to play two sides with

98 ibid 5.

99 ibid6-8.

100 Editorial, "Qatar Athletes" BBC.com (13 August 2012) Accessed on 10 August 2014. <http://www.bbc.com/sport/olympics/2012/countries/qatar/ athletes>

101 Editorial, "Qatar to Organize 43 International Sporting Events in the 2014/15 Season" Aroundtherings.com (26 March 2014) < http://aroundtherings.com/ site/A_46531/Title_Qatar-to-organise-43-international-sports-events-inthe-2014-15-season/292/Articles> accessed 10 August 2015.

102 ibid.

103 Malcolm Foley et al., "Policy Pragmatism: Qatar and the Global Events Circuit" (2012) 3(1), International Journal of Event and Festival Management 102, 111. 
its international relations - as a friend of both the West and the Arab world. Indeed, it would appear that part of Qatar's success must be credited to its flexible or malleable identity - a balancing act between a tempered Islamic outlook and a domestic approach to law and social affairs, as well as an often credible linkage to Nye's universal values, noted above, regarded as sacred by Western partners.

Apart from the above, Qatar actively uses a number of additional soft power tools, each of which contributes to its image and persuasive authority abroad, such as the continued expansion and growing attractiveness of Qatar Airways; active investment by Qatar's sovereign wealth fund into numerous successful brands, including the Volkswagen Automotive Group, Barclays Bank, Sainsbury supermarkets, Credit Suisse, Royal Dutch Shell, London's Olympic Village, Europe's tallest building, namely the "Shard" Harrods department store, Miramax Film Studios and the commodity trading house of Glencore, among others; ${ }^{104}$ Qatar's "rags-to-riches" story, as a state growing out of abject poverty in the 1940s; a progressive and westernized higher education system, hosted by the Qatar Foundation; ${ }^{105}$ and substantial efforts in growing foreign aid, ${ }^{106}$ as well as the international presence of its not-for-profit sector. ${ }^{107}$

\subsection{Identifying Results}

To summarize, we have thus far explored Qatar's foreign policy objectives, expanded on its desire to be an international soft power as compensation for a small stockpile of hard force utilities, as well as surveyed the list of soft power tools at its disposal. The tasks that remain are twofold, namely to identify the results of Qatar's efforts to exert influence via image, brand and persuasion in Africa; and second, to determine the associated problems that Qatar might have throughout these processes.

104 Camilla Hall et al, "Qatar: What's Next for the World's Most Aggressive Deal Hunter" Financial Times (4 July 2013) < http://www.ft.com/cms/s/2/ dc99ef1e-de45-11e2-9b47-00144feab7de.html\#slide0> accessed 10 August 2015; Editorial, "Disney Sells Miramax Film Studios" BBC.com (30 July 2010) <http://www.bbc.co.uk/news/business-10814344> accessed 10 August 2015

105 Osman (n 89) 41-42.

106 Ibid 46-47.

107 Fitch (n 72) 426. 


\subsection{Sudan}

Qatar has a number of high profile examples of successful mediation on the African continent, based on a number of different soft power factors. It is important to recall that Qatar was seen to use mediation efforts as a soft power tool in and of itself, as it seeks to carve out an image of an experienced mediator with a proven track record, a regional diplomatic powerhouse, an honest broker and a wise and mature international player, interested in peace both regionally and globally. ${ }^{108}$ Beginning with Sudan and Darfur, Qatar was named the Arab League's representative to mediate between the government in Khartoum and rebel factions, after violence between the two had escalated in 2008. ${ }^{109}$ Negotiations were hosted in Doha, along with mediators from the African Union, the United Nations, the Arab League and Sudan's regional neighbours. ${ }^{110}$

In spite of several failures to resolve the conflict, a ceasefire framework agreement was reached in February 2010, whereupon the Sudanese President, Omar al-Bashir, declared the conflict to be over. ${ }^{111}$ In 2011, this was followed by what has been popularly known as the Doha Peace Agreement, which solidified the previous accord between Sudan and the Justice and Equality Movement. The Norwegian PeaceBuilding Resource Centre credits this success, albeit temporary, to several factors attributable to Qatar's efforts at developing its own soft power image and persuasive capabilities. First, Qatar made the negotiations intensely personal, restricting participating mediators from Doha to the inner circle of the royal family. ${ }^{112}$ Equally, hosting talks in Doha was a crucial contribution from Qatar, resulting in an external perception of Doha as a neutral arena that affected negotiations positively. ${ }^{113}$ Second, Qatar used its economic model of state capitalism for political dividends throughout the peace process, both by emphasizing its already sizable investments in Sudan, as well as pledging

108 Kamrava (75) 542.

109 Kristian Coates Ulrichsen, “Qatar's Mediation Initiatives” (2013), Norwegian Peacebuilding Resource Centre Policy Brief 2.

110 ibid.

111 ibid.

112 ibid.

113 Sultan Barakat, “The Qatari Spring: Qatar's Emerging Role in Peacemaking" (2012) Brookings Institute and the London School of Economics and Political Science, 20-21. 
new infusions of financial resources, including US\$500 million for reconstruction assistance. ${ }^{114}$

The African Union itself noted that Qatar's investments in African countries, including Sudan, actively support the organization's efforts in resolving continental conflict and boosting African-Arab economic cooperation. ${ }^{115}$ Third and, most important, Qatar is said to have lacked the problematic historical baggage of the region's traditional heavyweights, including Egypt and Saudi Arabia, ${ }^{116}$ As Sudan had a troubled relationship with Egypt in particular. Qatar thus successfully employed its image as an impartial and honest third party to embed itself into the negotiation process. ${ }^{117}$

For Qatar, the soft power gains from its mediation efforts in Sudan were significant both in Africa and elsewhere as it was able to solidify its position as a viable, attractive and stable alternative diplomatic player with regard to Egypt and Saudi Arabia in particular, which was derived from its situational supplanting of the former; and it was able to use its successful, friendly image to back efforts to buy up farmland in Sudan under its National Food Security Programme. ${ }^{118}$ These successes are, for Barakat, rooted in a rare legitimacy held by Qatar, which was brought to the country by strategies of soft power, including developing a particular brand and linkages to "universal" norms. ${ }^{119}$

\subsection{Somalia}

Qatar was also named as one of the leading influential states in Somalia, via actions that are said to be part of a bigger push for soft power in the Horn of Africa. ${ }^{120}$ With a similar strategy to its efforts in Sudan,

114 ibid.

115 Editorial, “African Union Hails Qatar's Mediation Efforts in Darfur" Gulf Times (21 July 2014) <http://www.gulf-times.com/qatar/178/details/401361/ african-union-hails-qatar\%E2\%80\%99s-mediation-efforts-in-darfur $>$ accessed 11 August 2014.

116 ibid 2-3.

117 Ibid 3.

118 Kamrava (n 75) 542.

119 Malkhadir M. Muhumed, "Qatar's Influence in Somalia Edges Out Traditional Power-House Egypt" The East African (1 November 2013) <http:// www.theeastafrican.co.ke/news/Qatar-s-influence-in-Somalia-edges-Egypt-/ -/2558/2056248/-/item/0/-/pr0f13z/-/index.html> accessed 11 August 2014.

120 ibid 22. 
Qatar is placing itself, in contrast to Egypt, as a state with a history of engagement with Somalia. In 2011, carrot diplomacy seemed to have been successful with Somalia's Prime Minister, calling on Qatar to help achieve reconciliation between the various Somali factions and to assist with the state's reconstruction efforts. ${ }^{121}$ Indeed, Qatar Charity is seen to be one of the most active not-for-profit organizations operating in the country, including the launch of dedicated relief programmes during Somalia's recent famine. ${ }^{122}$ While Qatar may not necessarily have particularly evident foreign policy interests in Somalia, their engagement here serves to increase the Gulf state's brand, including local perspectives of its legitimacy and a positive image, which gives Qatar an influential foothold in the region.

\subsection{Mali and Tunisia}

In 2011, France sent military forces to Mali at the request of the local government to combat the rising threat of Islamic militia in the north of the country. Shortly thereafter, France began to accuse some of its allies, including Qatar, of working towards opposite goals. Qatar, it was argued, had been sending resources and money via its charity organizations to rebel-held areas in support of radical groups. ${ }^{123}$ Indeed, the Qatari Red Crescent was at one point during the conflict the only humanitarian organization to be granted access to the vast Northern Malian region. ${ }^{124}$ Analysis, however, suggests that Qatar's actions in Mali represent yet another attempt to build its soft power tool set

121 Habib Toumi, "Somalia Seeks Qatar Assistance in Country Reconciliation, Reconstruction" Gulf News (1 December 2011) < http://gulfnews.com/news/ gulf/qatar/somalia-seeks-qatar-assistance-in-country-reconciliationreconstruction-1.941540> accessed 11 August 2014.

122 Editorial, "UN Report: Qatar Charity Holds Second Position in Aiding the Somali People" Qatar Charity (16 August 2011) < http://qcharity.com/en/ index.php?option $=$ com_content $\&$ view $=$ article $\& i d=81$ : un-report-qatarcharity-holds-second-position-in-aiding-the-somali-people\&catid $=1$ : news\&Itemid $=50>>$ accessed 11 August 2014 .

123 Michael Stephens, "Guest Post: Here's What Qatar is Doing in Mali and Why" Doha News (24 January 2013) < http://dohanews.co/guest-post-heres-whatqatar-is-doing-in-mali-and/> accessed 11 August 2014.

124 Segolene Allemandou, "Is Qatar Fueling the Crisis in Northern Mali?"France 24(13 January 2013) < http://www.france24.com/en/20130121-qatar-malifrance-ansar-dine-mnla-al-qaeda-sunni-islam-doha/> accessed 11 August 2014. 
and, in particular for this state, see a return on its investment. Qatar has, in fact, engaged in carrot public diplomacy since the 1980s, establishing and funding a wide network of institutions, madrassas, schools and charities in Mali. ${ }^{125}$ It would appear as though Qatar's primary motivation for supporting the Islamist groups in various ways was to secure its own long-term business interests and increase its influence over rapidly changing events in the Muslim world. ${ }^{126}$ Indeed, for Qatar to be successful in Mali would mean a considerable boost in influence in Western Africa and the Sahel. Equally, Mali has extremely large deposits of oil and gas, as well as rare minerals, including gold and uranium. ${ }^{127}$ For a country like Qatar, its future security lies beyond its borders, via soft power influence, alliance building, and material investments. This strategy, operational as of July 2014, would appear to have been successful, as Mali recently awarded four mining exploration permits to Qatar. ${ }^{128}$

Another African state bearing witness to Qatar's rise in soft power, coupled with carrot diplomacy, is Tunisia. Qatar has invested substantially in Tunisia since the end of the Arab Spring, including US\$500 million to support Tunisia's reserve currency ${ }^{129}$ and the acquisition of a majority stake in major telecom and banking institutions. ${ }^{130}$ Indeed, while Qatar's image continues to grow in Tunisia,

125 ibid.

126 Anna Mahjar-Barducci, "Ruling Tunisia by Remote Control" Haaretz (27 January 2012) < http://www.haaretz.com/print-edition/opinion/rulingtunisia-by-remote-control-1.409416> accessed 11 August 2014.

127 Editorial," Who are Somalia's al-Shabab? "BBC.com (16 May 2014) < http:// www.bbc.com/news/world-africa-15336689>; Colum Lynch, "Qatar's Support for Islamists Muddles its Reputation as a Neutral Broker in Mideast" Washington Post(28 November 2018) < http://www.washingtonpost.com/ world/national-security/qatars-support-for-islamists-muddles-its-reputationas-neutral-broker-inmideast/2012/11/28/a9f8183a-f92e-11e1-83980327ab83ab91_story.html> accessed 11 August 2014.

128 Editorial, "Mali Grants Four Exploration Permits to Qatar Mining" Reuters (17 July 2014) <http://af.reuters.com/article/maliNews/idAFL6N0PS57 C20140717?pageNumber $=1$ \&virtualBrandChannel $=0>$ accessed 11 August 2014.

129 Editorial, "Update 2 - Qatar Bank Grants Tunisia \$500 mln to Support Currency Reserve" Reuters 23 (November2013) < http://www.reuters.com/article/ 2013/11/23/tunisia-economy-idUSL5N0J808320131123> accessed 11 August 2014.

130 Colin Kilkelly, “Qatar's Influence in Tunisia” Tunis Times (15 October 2013) <http://www.thetunistimes.com/2013/10/qatars-influence-in-tunisia91527/> accessed 11 August 2014. 
with a related improvement in soft power, some observers suggested that Qatar's influence in Northern Africa is similar to "ruling by remote control." 131

\section{PROBLEMS}

Unfortunately, Qatar's pristine reputation as a neutral broker of world conflict, crises and affairs, may have been muddied in recent years, due to several factors. The first is what I conceptualize as "failed soft power investments". As a firm on Wall Street might invest in a particular company, enterprise or resource and, as that investment might fail to return dividends or place that firm in a position less favourable than before, so too could countries make inappropriate soft power investments in opportunities that fail to produce targeted results. Qatar, in its quest to achieve soft power greatness, lost its critical balance of neutrality along the way, pushing further towards Islamic organizations that fail the test of universal values, as set out in the West. What are these failed investments? There is Qatar's apparent support of African Islamists, namely Somalia's al-Shabab insurgents, who were linked to numerous attacks in Somalia and Kenya. ${ }^{132}$ Furthermore, Israel charged that Qatar provided unbalanced financial support to Hamas in Gaza a charge that Qatar denied. ${ }^{133}$ Qatar made a significant soft power investment in Egypt's Muslim Brotherhood, shortly after the overthrow of former President Hosni Mubarak. ${ }^{134}$ Unfortunately for Qatar, shortly thereafter Egypt was once again thrown into turmoil and the Muslim Brotherhood was declared an illegal organization, leaving its soft power benefactor with a reputational bruise.

Qatar also finds itself in the difficult position of promoting universal Nye-esk values abroad but failing to practice them at home. A case in point is democracy. Qatar acts as its benevolent messenger

131 Anna Mahjar-Barducci (n 127).

132 BBC.com; Colum Lynch (n 128).

133 Sabina S. Khatri, "Qatar FM Hits Out at Israel Allegations About Funding Terrorism" Doha News (29 July 2014) < http://dohanews.co/qatar-fm-hitsisrael-allegations-funding-terrorism/> accessed 10 August 2014.

134 Frida Ghitis, "World Citizen: Qatar's Risky Bet on the Muslim Brotherhood" World Politics Review (31 January 2013) < http://www.worldpoliticsreview. com/articles/12678/world-citizen-qatar-s-risky-bet-on-the-muslimbrotherhood $>$ accessed 10 August 2014. 
internationally, but domestically it has been ranked near the bottom of The Economist's Economic Intelligence Unit Democracy Index. ${ }^{135}$ For Nye, promoting a set of political values could be a major boost to soft power influence, but only when the promoter adheres to them both at home and abroad and pursues foreign policies regarded as legitimate and having moral authority. ${ }^{136}$ In short, Qatar's efforts abroad may end up lacking in substance as it fails to "lead by example."137

Qatar may realize that there are limits to its carrot diplomacy or soft power bolstered by financial and resource inducements. For Nye, when you can get others to admire your ideals and get them to do what you would like them to do, then you should not have to spend much on sticks or carrots to move them in the direction of your choice. ${ }^{138}$ For Antwi-Boateng, Qatar, as a new state with a malleable identity and developing priorities, is not universally identified with a particular set of values or ideals that others will voluntarily embrace without inducements - therefore the question is, what would happen if and when Qatar runs out of "carrots" to bolster its diplomacy and soft power?

Along a similar line of thought, Khatib argues that Qatar's foreign policy is not based on a cohesive political strategy but rather seems to be perpetually playing catch-up with political trends in being reactive to them rather than setting the international normative agenda. ${ }^{139}$ Qatar needs to be the first state to espouse a particular perspective attractive to others, rather than simply falling in line.

Finally, in terms of its quintessential soft power strategy of mediation, Qatar seemingly lacks the administrative and on-the-ground resources to translate initial agreements into sustainable resolutions of disputes. ${ }^{140}$ Its current diplomatic service is too small to follow up or monitor progress towards implementation after negotiations have ended, meaning that, in cases such as Darfur, Qatar's efforts were more about bridging surface divisions rather than actually addressing deeper structural concerns. ${ }^{141}$ Even those results could be considered as shortlived. Khatib notes that, while Qatar's diplomatic endeavours were

135 Osman (n 89)47.

136 ibid 47-48.

137 ibid 48.

138 ibid.

129 Fitch (n 72) 429.

140 Gulf Times (n 117) 3.

141 ibid. 
traditionally hailed as successful, their effect has generally been limited to the short-term. ${ }^{142}$ Thus, for Qatar to truly become an authoritative and effective soft power, evoking meaningful and long-lasting change, the above difficulties and lessons learned must be taken to account.

\subsection{Alternative Strategies}

If Qatar fails in its soft power approach by gaining only limited international prestige and influence - are there alternative strategies that it could pursue? This article proposes at least two. The first is "smart power", a term credited to Nye and Suzanne Nossel. ${ }^{143}$ Smart power is defined as neither hard nor soft power, but rather the "skilful combination of both". It is the development of an integrated strategy, resource base and a tool-kit to achieve foreign policy objectives drawing on both types of power. ${ }^{144}$ It is an approach that recognizes the need for both an effective military and economic resources set, but is also heavily invested in the belief that alliances, partnerships and the development of a recognizable and desired image abroad, associated with clear, universal values and norms, is crucially necessary. ${ }^{145}$ Smart power equally understands that every dollar spent on hard power will not necessarily bring with it a dollar's worth of security. ${ }^{146}$ In the words of Nye, smart power is the exporting of optimism, not fear. ${ }^{147}$

In several ways, it would appear as though Qatar might have already started to move down a path of smart power. While this article focused on soft power initiatives and principles, the other half of the smart power equation appears to have established some roots. Qatar started to deepen its cooperation with NATO and Western militaries, as can be seen during the former's recent sortie to Libya. ${ }^{148}$ Qatar recently signed a 10-year defence cooperation agreement with the United States (as well as playing host to its military bases); and, it has begun to upgrade

142 Fitch (n 72) 429.

143 Suzanne Nossel, "Smart Power" (2004) 83(2) Foreign Affairs, 131-142.

144 Richard L. Armitage and Joseph S. Nye Jr., "CSIS Commission on Smart Power - A Smarter, More Secure America" (2007), Centre for Strategic and International Studies 7.

145 ibid.

146 ibid 10.

147 ibid.

148 Editorial, "NATO and Gulf Countries Determined to Deepen Cooperation" NATO - Newsroom (2 April 2014) < http://www.nato.int/cps/en/natolive/ news_108674.htm?selectedLocale $=$ en $>$ accessed 10 August 2014. 
and update its hard power equipment via deals with both the US and France, while continuing its pursuit of soft power influence. ${ }^{149}$

The second alternative strategy for Qatar could be to follow in the footsteps of the European Union and become what some term as a "normative power" or civilian power. The notion of normative power largely rests within a discussion of the power over opinion, an idéeforce or ideological power. ${ }^{150}$ Looking at it in another way, normative power has the potential to influence activities via the power of norms, shaping what constitutes both the domain and range of legitimate behaviour for other actors. ${ }^{151}$ Normative power is the ability to frame what is acceptable and what is not - both internationally and in the domestic context of another state. ${ }^{152}$ Jackson argues that, while the ability to define normality might be the ultimate source of power in the international system, the legitimacy of those definitions is not assumed, but it must rather be earned. ${ }^{153}$

Evidently, normative power must rest on what Manners terms a country's normative basis, typically developed via policy, culture and society over a non-specific period of time. ${ }^{154}$ For example, the European Union, as an organization, has spent nearly 50 years building its normative basis that provides a centrality for peace, liberty, democracy, respect for the rule of law and the protection of human rights. ${ }^{155}$ But having a normative base is not sufficient to be considered a normative power - instead, there should be efforts to diffuse those norms abroad, resulting in an explicit or implicit change in a targeted recipient. Manners argues that there are at least six means by which this diffusion can occur, namely contagion; the unintentional diffusion of norms from one actor to another; informational or diffusion via a range of strategic communications; procedural, as in the institutionalization of a relationship between states; transference, via the exchange of goods, aid or technical assistance; overt diffusion or the physical presence of State A

149 Al-Jazeera.com (n 92) 2-6.

150 Ian Manners, "Normative Power Europe: A Contradiction in Terms?" (2002) 40(2), Journal of Common Market Studies, 239.

151 Emilian Kavalski, "The Struggle for Recognition of Normative Powers: Normative Power Europe and Normative Power China in Context" (2013) 48(2), Cooperation and Conflict, 248.

152 ibid.

153 ibid.

154 Manners (n 151) 242.

155 ibid. 
in State B; and a cultural filter, based on the interplay between the creation of knowledge, namely the social and political learning in third states. ${ }^{156}$ Perhaps then, if Qatar can continue to differentiate itself from its regional neighbours by its ability to balance religious obligations with universal/western interests and ideology both domestically and abroad, it could solidify itself as a legitimate normative model that can influence others.

A third and final alternative strategy group, albeit one that can play a collaborative role with soft power above, is the use of various emerging forms of diplomacy, such as networking; celebrities entering the ring; and the presence of guerrilla forces. Networking diplomacy, as opposed to club diplomacy, uses a less hierarchical model of interaction in which diplomats engage with a vastly larger number of players in the host country, which becomes particularly crucial when a state is attempting to diffuse a particular image or brand of itself over a much wider, globalized society as a means of gaining soft power. ${ }^{157}$ The second is celebrity diplomacy or the participation of well-known, pre-branded individuals who participate in everything from formal negotiations between states to the increase of public awareness in terms of a particular issue. ${ }^{158}$ Celebrity involvement in diplomatic activities is attractive, as they are able to find a populist recognition and legitimacy that they are unable to cultivate on their own and, once within traditional spheres of negotiations, they can advance particular agendas directly with state leadership. ${ }^{159}$ Finally, there is guerrilla diplomacy, or the veritable boots-on-the-ground diplomacy, once reserved for the world of human intelligence operatives, whereby diplomats would provide the vital functions of networking, advocacy and an analysis of crucial events for their home state via non-traditional mediums, such as a storefront presence, temporary missions, co-location with suitable partners, the use of large expatriate communities for brand diffusion and the expansion of honorary consuls. ${ }^{160}$

156 Ibid 244-245.

157 Jorge Heine, "On the Manner of Practising the New Diplomacy" (Centre for International Governance Innovation Working Paper 11, 2006), 3-5.

158 Andrew F. Cooper, "Celebrity Diplomacy and the G8: Bono and Bob as Legitimate International Actors" (Centre for International Governance Innovation Working Paper 29, 2007), 1-2.

159 ibid.

160 Daryl Copeland, "Guerrilla Diplomacy: Delivering International Policy in a Digital World" (2004) 11(2), Canadian Foreign Policy Journal, 174. 


\section{CONCLUSION}

Qatar has shown emerging international power as a small Gulf State with substantial hard economic resources. There appears to be, however, an inconsistency in Qatar's foreign policy associated with soft power objectives and definitions. While Qatar has an extensive soft power toolset, each power tool is designed to extend a welcoming and attractive brand or image abroad as a means of persuading targeted states to move closer to Qatar. An examination of available evidence outlining Qatar's attempted soft power actions on the African continent did indeed highlight its significant use, albeit from a slightly different angle than its western soft power predecessors. It primarily uses what is termed as carrot diplomacy or the influencing of others, backed by material and financial resource inducements. This article identified five problems and roadblocks affecting Qatar's approach to international relations, which was followed by alternative power-based strategies, which could be explored by its governing bodies.

While Qatar may already possess significant soft power, including on the African continent, such power was created primarily via hard financial investments rather than an image associated with desirable universal values. Therefore, the key will be for Qatar to sustainably invest in its future soft power image, in the same way it did for future food and economic security. Using the available time and resources to build an attractive reputation, non-reliant on the continued influx of material resources, avoiding an imbalance of polarized normative camps; creating for itself a distinct brand associated with universal values practiced abroad and at home; and adhering to the lessons presented, may very well be the path that leads to an international respect for Qatar - long after its cheques can no longer be signed. 